\title{
AVALIAÇÃO DO EFEITO DE SUBSTÂNCIAS ANTIOXIDANTES NO CRESCIMENTO DE CULTURAS CELULARES DE CANA-DE-AÇÚCAR (Saccharum spp.)
}

\author{
Bruno de Lima Melo ${ }^{1}$, Iris Glaucia Guedes de Moura Lima ${ }^{2}$, Antonio Fluminhan ${ }^{1,2}$
}

Universidade do Oeste Paulista - UNOESTE. ${ }^{1}$ Curso de graduação em Ciências Biológicas. ${ }^{2}$ Curso de Mestrado em Agronomia, Presidente Prudente, SP. e-mail: $\underline{\text { fluminhan@unoeste.br }}$

\section{RESUMO}

Esta pesquisa teve por objetivo avaliar culturas celulares estabelecidas a partir de meristemas apicais de dois cultivares de cana-de-açúcar: SP 813250 e RB 845210, com vistas à identificação das melhores combinações entre material biológico e composições de meios de cultivo, que assegurem uma elevada capacidade de manutenção no cultivo in vitro, com multiplicação celular mesmo após longos períodos. Meios de cultivo preparados com sais de Murashige-Skoog foram acrescidos de ácido ascórbico, glicina, glutamina, ácido nicotínico, prolina, piridoxina, tiamina, ácido aspártico e arginina, além de sacarose, inositol e a auxina 2,4-D. As avaliações das taxas de crescimento e proliferação celulares foram realizadas através da mensuração do peso vivo das culturas após a manutenção por período de tempo determinado em meios com composições diferentes. Foi observado que a adição de substâncias antioxidantes ao meio de cultivo proporcionou uma maior viabilidade das culturas e maior taxa de proliferação celular. Foram observadas taxas de crescimento de até $500 \%$ das culturas celulares mantidas por 30 dias em meio modificado, em comparação a taxas ao redor de $230 \%$ em culturas mantidas por igual período no meio original. Esta nova formulação se mostrou mais eficaz em manutenção das culturas celulares por longos períodos de cultivo in vitro.

Palavras-chave: cana-de-açúcar, antioxidantes, envelhecimento celular, estresse oxidativo, biotecnologia vegetal.

\section{EVALUATION OF ANTIOXIDANT EFFECT OF SUBSTANCES ON GROWTH OF SUGAR CANE (Saccharum spp.) CELL CULTURES}

\begin{abstract}
This research aimed to evaluate cell cultures initiated from meristem apices removed from two genotypes of sugarcane: SP 813250 and RB 845210, in order to identify the best combinations between biological material and compositions of culture media, which ensure high maintenance during in vitro culture, and high potential of cell proliferation even after long periods. Culture media prepared with Murashige-Skoog salts had addition of ascorbic acid, glycine, glutamine, nicotinic acid, proline, pyridoxine, thiamine, aspartic acid and arginine, and sucrose, inositol, and 2,4-D auxin. Evaluation of cell growth rates and cell proliferation were performed by means of measurements of the fresh weight of the cultures after maintenance for a determined period on media with different compositions. It was observed that the addition of antioxidants to the culture medium provided a higher viability of the cultures and higher proliferation rate. Growth rates were observed up to $500 \%$ of the cell cultures maintained for 30 days on modified medium, compared with rates of around $230 \%$ in cultures maintained for the same period in the original medium. This new formulation was more effective in maintaining cell cultures for extended periods of in vitro culture.
\end{abstract}

Keywords: sugarcane, antioxidants, cell aging, oxidative stress, plant biotechnology. 


\section{INTRODUÇÃO}

A cana-de-açúcar é uma planta que pertence à família Poaceae (Gramineae) e gênero Saccharum sendo que os seus produtos são largamente utilizados na produção de alimentos e energia. Do seu processo de industrialização obtêm-se produtos como o açúcar, nas suas mais variadas formas e tipos, o álcool anidro e hidratado, o vinhoto, a torta de levedura, o bagaço e, mais recentemente, o biodiesel ${ }^{1}$. Esta cultura é considerada a principal biomassa energética atual no mundo, e possui notória importância no cenário econômico e social brasileiro. Em decorrência da posição de destaque que ocupa, a cultura está frequentemente inserida em pesquisas visando à resistência a pragas, patógenos, tolerância a herbicida e aumento no teor de sacarose $^{1}$.

Por sua vez, as pesquisas em biotecnologia para a área vegetal têm evoluído através de inúmeras técnicas, tais como: o desenvolvimento de sistemas visando à manipulação genética e celular, a seleção in vitro e propagação de genótipos superiores, entre outras ${ }^{2}$. Entretanto, para que possam ser utilizadas nestas aplicações, é necessário que as culturas celulares empregadas mantenham uma elevada capacidade de regeneração de plantas completas, e sem a ocorrência de variação genética, mesmo após longos períodos de cultivo in vitro ${ }^{3}$.

Em programas de melhoramento genético da cana-de-açúcar que empregam técnicas de biotecnologia, em específico, Lee ${ }^{4}$ ressalta que há a necessidade, sob determinadas circunstâncias, de se multiplicar o material selecionado com rapidez, selecionando-se os genótipos que apresentam maior capacidade de regeneração de plantas.

A presente pesquisa procurou avaliar o efeito antioxidante de diversas substâncias em culturas celulares mantidas in vitro oriundos de genótipos de alto valor agronômico, de modo a criar sistemas de multiplicação massal e com elevado potencial morfogenético. Dentro do programa de pesquisa proposto, tem-se por objetivos: a) Identificar as melhores combinações entre genótipos e meios de cultivo que apresentam características favoráveis de elevado potencial morfogenético, que é considerado imprescindível para o emprego de técnicas biotecnológicas no melhoramento genético desta espécie; b) Padronizar a formulação de um meio de cultivo que se mostre mais eficaz para a manutenção das culturas celulares por longos períodos de tempo in vitro; c) Determinar qual efeito que as substâncias antioxidantes, tais como: ácido ascórbico, entre outras, pode desempenhar no processo de envelhecimento celular vegetal. 


\section{METODOLOGIAS}

Os genótipos de cana-de-açúcar avaliados foram dois dos mais cultivados por uma das maiores empresas do setor de produção sucroalcooleira na região do Oeste Paulista, a Usina Alto Alegre S.A. - Açúcar e Álcool, que possui sede no município de Presidente Prudente (SP). Os materiais biológicos gentilmente cedidos e removidos da área de produção agrícola da referida empresa foram os cultivares: SP 813250 e RB 845210. O trabalho foi realizado no Laboratório de Citogenômica e Bioinformática da Universidade do Oeste Paulista - Unoeste. As culturas celulares foram iniciadas em outubro de 2010 e as mesmas estão sendo mantidas cultivas in vitro até os dias atuais.

As culturas foram mantidas in vitro em condições de escuro e a uma temperatura de aproximadamente $25^{\circ} \mathrm{C}$, e os meios de cultivo foram renovados a cada 30 dias, transferindo-se as regiões com maior taxa de crescimento e aspecto viável.

Para a verificação da taxa de crescimento das culturas celulares induzidas, foram coletados fragmentos de culturas celulares dos dois cultivares avaliados nesta pesquisa, com cerca de $200 \mathrm{mg}$ cada um e inoculados em dois meios de cultivos distintos. Fragmentos de dimensões iguais e semelhante peso fresco foram introduzidos em proporções iguais para a realização das análises comparativas dos efeitos dos compostos do meio de cultivo. Foram utilizados quatro frascos de mesmo meio de para cada cultivar, contendo quatro explantes cada um.

\section{Cultivo In vitro e coleta de dados}

As culturas celulares foram iniciadas a partir de meristemas apicais, que foram utilizados como explantes dos genótipos avaliados. Estes foram isolados conforme procedimentos padronizados para a espécie e descritos na literatura ${ }^{1,2,4}$, e cultivados em dois meios de cultivo com composições distintas. Os genótipos empregados nesta pesquisa foram avaliados em relação à formação de culturas celulares e taxa de crescimento durante o cultivo em meios com composições apresentadas no Quadro 1.

As avaliações das taxas de crescimento e proliferação celulares foram realizadas através da mensuração do peso total das culturas celulares após um período de trinta dias em meios com composições diferentes. Antes e após este período, as culturas foram analisadas visualmente $e$ submetidos à mensuração de seu peso fresco com o emprego de balança analítica.

\section{Composições dos Meios de Cultivo}

Um dos meios avaliados, denominado "original", foi preparado com sais $\mathrm{MS}^{5}$, enquanto que o segundo meio, denominado 
"modificado", consistiu na composição salina do meio MS acrescido de ácido ascórbico, glicina, glutamina, ácido nicotínico, prolina, piridoxina, tiamina, ácido aspártico e arginina, além de sacarose, inositol e a auxina 2,4-D, e cujas concentrações estão anotadas no Quadro 1.

Os meios de cultivo se diferenciam, principalmente, em relação aos níveis de compostos orgânicos, aminoácidos e vitaminas. Ressalta-se que o primeiro meio apresenta menor número destas substâncias (ácido nicotínico, piridoxina, tiamina, glicina e ácido ascórbico), enquanto o meio modificado apresenta maior diversidade, pois contêm todas aquelas substâncias presentes no meio original, mas com o acréscimo de: glutamina, prolina, ácido aspártico e arginina.

Quadro 1. Composições de meios para o cultivo in vitro e avaliação da taxa de crescimento de culturas celulares induzidas a partir de meristemas apicais dos cultivares de cana-de-açúcar SP 813250 e RB 845210.

\begin{tabular}{|c|c|c|}
\hline COMPONENTES & MEIO ORIGINAL MS ${ }^{5}$ & MEIO MODIFICADO \\
\hline & $\mathrm{mg} / \mathrm{L}$ & $\mathrm{mg} / \mathrm{L}$ \\
\hline Nitrato de Potássio - $\mathrm{KNO}_{3}$ & $1.900,0$ & $1.900,0$ \\
\hline Cloreto de Cálcio - $\mathrm{CaCl}_{2} \cdot 2 \mathrm{H}_{2} \mathrm{O}$ & 440,0 & 440,0 \\
\hline Sulfato de Magnésio - $\mathrm{MgSO}_{4} \cdot 7 \mathrm{H}_{2} \mathrm{O}$ & 370,0 & 370,0 \\
\hline Fosfato de Potássio - $\mathrm{KH}_{2} \mathrm{PO}_{4}$ & 170,0 & 170,0 \\
\hline Nitrato de Amônio - $\mathrm{NH}_{4} \mathrm{NO}_{3}$ & $1.650,0$ & $1.650,0$ \\
\hline Ácido Bórico $-\mathrm{H}_{3} \mathrm{BO}_{3}$ & 6.2 & 6.2 \\
\hline Sulfato de Manganês - $\mathrm{MnSO}_{4} \mathrm{H}_{2} \mathrm{O}$ & 22.3 & 22.3 \\
\hline Sulfato de Zinco - $\mathrm{ZnSO}_{4} 7 \mathrm{H}_{2} \mathrm{O}$ & 8.6 & 8.6 \\
\hline Molibdato de Sódio $-\mathrm{Na}_{2} \mathrm{MoO}_{4} \cdot 2 \mathrm{H}_{2} \mathrm{O}$ & 0.25 & 0.25 \\
\hline Sulfato de Cobre - $\mathrm{CuSO}_{4.5} 5 \mathrm{H}_{2} \mathrm{O}$ & 0.025 & 0.025 \\
\hline Cloreto de Cobalto $-\mathrm{CoCl}_{2} \cdot 6 \mathrm{H}_{2} \mathrm{O}$ & 0.025 & 0.025 \\
\hline lodeto de Potássio - KI & 0.83 & 0.83 \\
\hline Ácido Nicotínico & 0.5 & 0,92 \\
\hline Piridoxina $\mathrm{HCl}$ & 0.5 & 3,84 \\
\hline Tiamina $\mathrm{HCl}$ & 1.0 & 5,06 \\
\hline Glicina & 2.0 & 0,75 \\
\hline Ácido Ascórbico & 3.0 & 1,76 \\
\hline Glutamina & & 1,46 \\
\hline Ácido Aspártico & & 1,33 \\
\hline Prolina & & 1,15 \\
\hline Arginina & & 1,74 \\
\hline Inositol & 100,0 & 100,0 \\
\hline Sacarose & $30.000,0$ & $30.000,0$ \\
\hline Auxina $(2,4-D)$ & 5,0 & 5,0 \\
\hline $\mathrm{FeSO}_{4} 7 \mathrm{H}_{2} \mathrm{O}$ & 27,8 & 27,8 \\
\hline $\mathrm{Na}_{2}$ EDTA. $2 \mathrm{H}_{2} \mathrm{O}$ & 37,2 & 37,2 \\
\hline
\end{tabular}


Ambas composições apresentam igual concentração de: Inositol (100 mg/L), Ferro EDTA, sacarose (30 g/L) e auxina 2,4-D $(5 \mathrm{mg} / \mathrm{L})$, para a indução e manutenção de calogênese. Ambos meios foram solidificados com ágar ( $9 \mathrm{~g} / \mathrm{L})$, e tiveram o seu potencial hidrogeniônio ajustado previamente à adição de ágar, para valor de $\mathrm{pH}$ 6,3, para que resultassem em pH 5,8 após a autoclavagem a 1 atmosfera por 20 minutos $^{3}$.

\section{ANÁLISES ESTATÍSTICAS}

Os valores obtidos com a mensuração da taxa de crescimento das culturas celulares foram submetidos à análise de variância, e os efeitos das interações dos cultivares com meios de cultivo foram avaliados. Foi realizado o teste $\mathrm{F}$ para se avaliar a influência devido ao efeito dos diferentes cultivares, segundo o modelo inteiramente casualizado, com o emprego do software ASSISTAT ${ }^{6,7}$. Foi realizado o teste $\mathrm{F}$ também para se avaliar $\mathrm{o}$ efeito de meios de cultivo e as interações existentes entre meios x cultivares. Quando o valor de $\mathrm{F}$ foi significativo ao nível de $5 \%$ de probabilidade, foi realizado o teste de Tukey, para a comparação de contrastes entre médias dos materiais ${ }^{6,7}$. Como medida de dispersão dos dados, foram calculados os coeficientes de variação (C.V.) para os valores das taxas de crescimento das culturas celulares induzidas em cada cultivar avaliado.

\section{RESULTADOS}

As culturas celulares induzidas a partir de meristemas apicais foram mantidas através de sucessivas transferências de meios de cultivo, com o objetivo de manter a elevada capacidade de proliferação celular dos cultivares avaliados ${ }^{8}$. Em ambos genótipos, a taxa de indução de calos a partir dos meristemas apicais foi superior a $90 \%{ }^{8}$. Os calos induzidos foram subcultivados a cada 30 dias, removendo-se as regiões dos calos com maior vigor e crescimento, visando ao estabelecimento de culturas com grande capacidade de proliferação.

Foi observado um pronunciado efeito provocado pelo cultivo dos calos nas duas composições de meios de cultivo. Dados coletados das culturas celulares de ambos genótipos permitiu a verificação de um comportamento diferenciado em relação à taxa de proliferação celular. Logo nos primeiros 30 dias de cultivo, as culturas celulares mantidas no meio de cultivo modificado exibiram coloração mais clara, maior taxa de crescimento e grande vigor, quando comparadas com as culturas celulares mantidas em meio de cultivo original. Esta observação demonstra a existência de um efeito claramente benéfico devido à presença de compostos orgânicos no meio de cultivo modificado, conforme pode ser observado na Figura 1. 


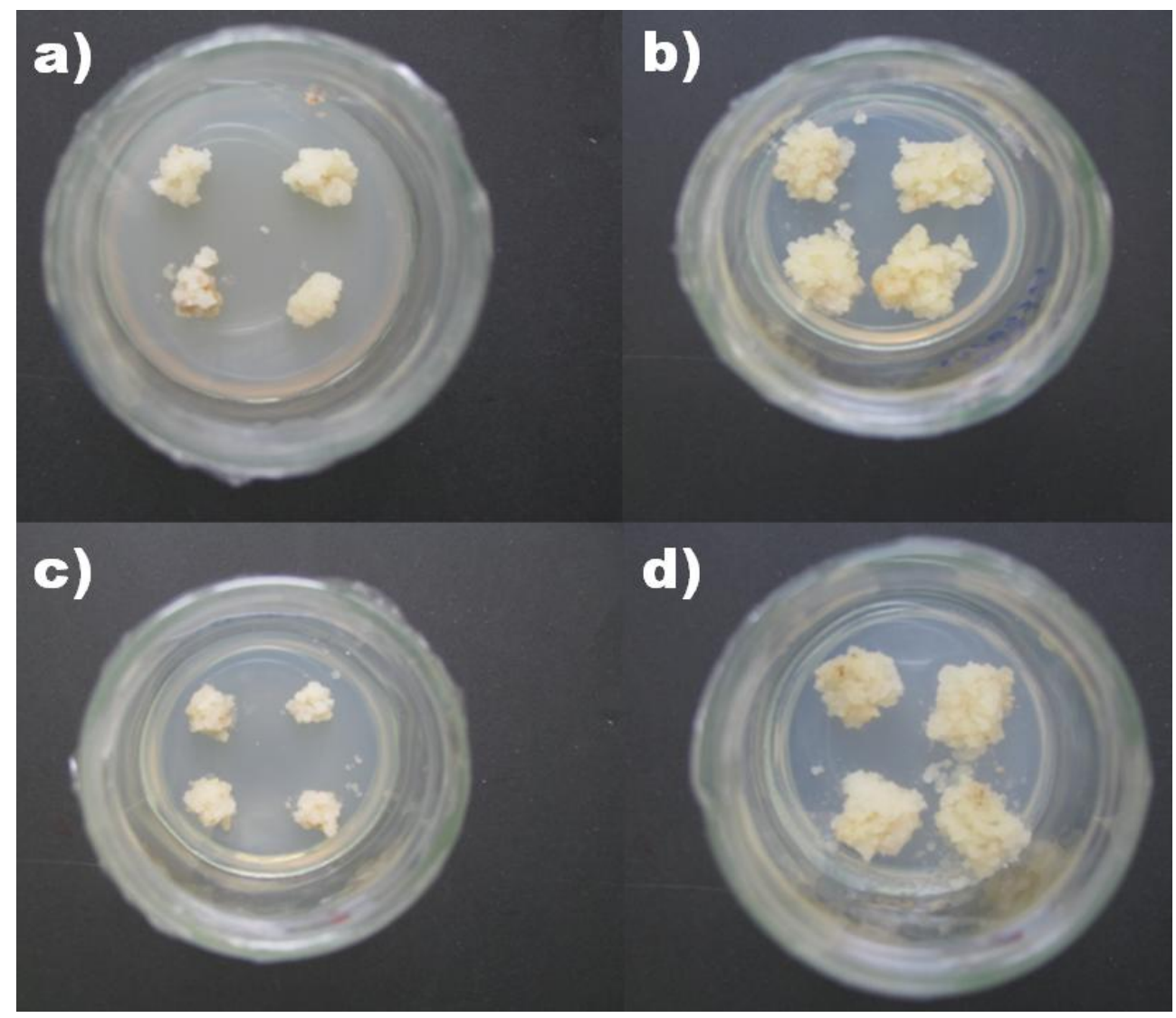

Figura 1. (a) Culturas celulares do cultivar SP 813250 após 30 dias de manutenção em meio original MS e (b) Cultivos celulares do mesmo genótipo mantidas em meio modificado após os mesmos trinta dias. (c) Culturas celulares induzidas a partir do genótipo RB 845210, após 30 dias de cultivo em meio MS original e (d) Culturas do mesmo genótipo mantidas após 30 dias em meio modificado.

Fonte: Os autores

Os resultados apresentados nas Tabelas 1 e 2 indicam o crescimento das culturas celulares dos dois cultivares de canade-açúcar que foram avaliadas nesta pesquisa, após 30 dias de cultivo nos dois meios com diferentes composições. Os dados referem-se a médias e taxas de crescimento observadas em quatro frascos de ambos os meios de cultivo, contendo quatro calos em cada um deles, os quais foram pesados antes e após 30 dias de cultivo.
Observou-se que o crescimento dos calos após manutenção em meio modificado foi aproximadamente cinco vezes maior do que o observado em calos mantidos no meio original. As pesagens dos calos foram realizadas em balança analítica de modelo Shimadzu AUY 220.

Quando mantidos no meio de cultivo modificado, os calos induzidos a partir de tecidos das duas variedades apresentaram um crescimento pronunciado, e exibiram vigor e características morfológicas 
superiores (friabilidade e possibilidade de formação de novas colônias), em comparação com as culturas celulares mantidas no meio MS original.

Tabela 1. Variação (\%) do peso fresco das culturas celulares induzidas a partir de meristemas apicais dos cultivares SP 813250 e RB 845210 após 30 dias de cultivo no meio MS original.

Taxa de crescimento de culturas celulares (em \% do peso vivo) após 30 dias de cultivo em meio MS original (Peso inicial - Peso final) / Peso inicial * 100

\begin{tabular}{|c|c|c|c|c|}
\hline $\operatorname{Frascos}(*)$ & \multicolumn{2}{|c|}{ Cultivar SP $813250\left({ }^{* *}\right)$} & \multicolumn{2}{|c|}{ Cultivar RB $845210(* *)$} \\
\hline 01 & $261,45^{b}$ & $195,44^{d}$ & 284,70 a & $186,95^{d}$ \\
\hline 02 & $234,12^{c}$ & $136,88^{\mathrm{e}}$ & $210,00^{c}$ & $133,15^{\mathrm{e}}$ \\
\hline 03 & $217,63^{c}$ & $291,47^{a}$ & $321,62 \underline{a}$ & $302,57 \underline{a}$ \\
\hline 04 & $290,15^{a}$ & $184,00^{d}$ & $198,06^{d}$ & $219,53^{c}$ \\
\hline Média & \multicolumn{2}{|c|}{$226,39^{c}$} & \multicolumn{2}{|c|}{$232,07^{c}$} \\
\hline
\end{tabular}

Tabela 2. Variação (\%) do peso fresco das culturas celulares induzidas a partir de meristemas apicais dos cultivares SP 813250 e RB 845210 após 30 dias de cultivo no meio MS modificado.

Taxa de crescimento de culturas celulares (em \% do peso vivo) após 30 dias de cultivo em meio MS modificado (Peso inicial - Peso final) / Peso inicial * 100

\begin{tabular}{ccccc} 
Frascos $\left(^{*}\right)$ & \multicolumn{2}{c}{ Cultivar SP $813250\left({ }^{* *}\right)$} & \multicolumn{2}{c}{ Cultivar RB $845210\left(^{* *}\right)$} \\
$\mathbf{0 1}$ & $903,55^{\mathrm{a}}$ & $894,68^{\mathrm{a}}$ & $604,50^{\mathrm{b}}$ & $737,98^{\mathrm{a}}$ \\
$\mathbf{0 2}$ & $494,60^{\mathrm{c}}$ & $491,62^{\mathrm{c}}$ & $314,12^{\mathrm{e}}$ & $307,98^{\mathrm{e}}$ \\
$\mathbf{0 3}$ & $368,30^{\mathrm{d}}$ & $457,14^{\mathrm{c}}$ & $297,59^{\mathrm{e}}$ & $438,64^{\mathrm{c}}$ \\
$\mathbf{0 4}$ & $449,01^{\mathrm{c}}$ & $362,75^{\mathrm{d}}$ & $420,97^{\mathrm{c}}$ & $404,85^{\mathrm{c}}$
\end{tabular}
Média
$552,70^{b}$
$440,82^{c}$

$(*)$ Refletem a média de quatro culturas celulares por frasco de cultivo.

$\left({ }^{* *}\right)$ As médias seguidas pela mesma letra não diferem estatisticamente entre si. Foi aplicado o teste de Tukey ao nível de $5 \%$ de probabilidade. 
A análise comparativa do crescimento das culturas celulares de cana-de-açúcar para a observação da taxa de crescimento dos dois genótipos inoculados no meio de cultivo MS, mostrou que os mesmos exibiram uma baixa taxa de crescimento no decorrer de 30 dias, variando ao redor de $230 \%$ de crescimento. Além disto, foi notada a presença de oxidação em algumas culturas, como indício de baixo vigor dos calos. Em relação ao meio de cultivo modificado ambos genótipos SP 813250 e RB 845210 apresentaram uma elevada taxa de crescimento, variando ao redor de $440 \%$ a $550 \%$ ao longo de 30 dias, mas com calos atingindo até mesmo $900 \%$ de taxa de crescimento neste período, com a formação de massa celular bastante friável. Ressalta-se que não foi observada oxidação das culturas e, ao contrário, constatou-se uma coloração muito mais exuberante em comparação aos calos cultivados sob meio de cultivo original.

\section{DISCUSSÃO}

A partir das observações realizadas pode-se verificar que a formulação de um novo meio de cultivo, denominado "meio modificado", se mostrou bastante eficaz em relação à possibilidade de elevação da taxa de crescimento in vitro de culturas de células de cana-de-açúcar. Essa estratégia permite explorar o máximo de proliferação celular com poucas modificações na composição dos meios de cultivo, que foi uma ideia já preconizada como um dos principais gargalos na pesquisa em biotecnologia vegetal ${ }^{9}$. Conforme mencionado por Morini et al. ${ }^{10} \mathrm{e}$ Ertola et al. ${ }^{11}$, modificações na composição de meios de cultivo podem resultar em muitos benefícios para o cultivo de células vegetais e o desenvolvimento de novas pesquisas científicas na área, em especial, para a sua utilização em bioreatores vegetais.

Isso mostra que a adição das substâncias em questão (glutamina, prolina, ácido aspártico e arginina) foi benéfico para o cultivo celular de cana-de-açúcar, auxiliando os programas de melhoramento com o emprego de biotecnologia, com a possibilidade de colaborar para as pesquisas envolvendo a manipulação genética das plantas, o desenvolvimento de híbridos somáticos e a produção de plantas transgênicas. Conforme já discutido por outros autores ${ }^{12}$, os primeiros passos para o uso destas técnicas em sistemas automatizados será o desenvolvimento de protocolos específicos que permitam os cultivos assépticos das células e tecidos vegetais in vitro, com a manutenção da capacidade de regeneração de plantas.

As culturas celulares induzidas a partir dos explantes dos genótipos avaliados apresentaram uma alta taxa de crescimento, mantendo o vigor, mesmo após vários meses de cultivo in vitro. Para a realização do 
presente estudo com antioxidantes, com o intuito de buscar uma melhor compreensão da ação sobre o estresse oxidativo, viabilidade das culturas, mantidas após o longo período na forma de calos, é sem dúvida um indicativo muito promissor no sentido de emprego da mesma metodologia na biotecnologia vegetal ${ }^{13,14}$.

Logo nos primeiros dias de cultivo em meio modificado, já foi possível observar que as culturas apresentavam um comportamento diferente, mostrando que a presença dos compostos antioxidantes e protetores celulares foi extremamente benéfica, com a exibição de maior taxa de crescimento que permaneceu por vários meses. Sabe-se que em sistemas de bioreatores, a longevidade das culturas celulares é um dos fatores que desperta maior preocupação dos pesquisadores ${ }^{11,15-17}$.

\section{CONCLUSÕES}

Foi observado que a adição de substâncias antioxidantes e aminoácidos aos meios de cultivo resultou em maior viabilidade e sobrevivência das culturas celulares e maior taxa de proliferação durante o cultivo in vitro. Com isso foi possível padronizar no laboratório um novo meio de cultivo, aqui denominado "meio modificado", que passou a ser empregado como meio padrão, pois o mesmo se mostrou mais eficaz em manutenção dos calos por longos períodos de cultivo in vitro. Os próximos passos certamente envolverão a avaliação da manutenção da capacidade de regeneração de plantas, resultando em uma multiplicação clonal rápida, e produção de mudas livres de pragas e patógenos.

\section{REFERÊNCIAS}

1 Cidade DAP, Garcia RO, Duarte AC, Sachetto-Martins G, Mansur E. Morfogênese in vitro de variedades brasileiras de cana-deaçúcar. Pesqui Agropecu Bras 2006; 41(3):385-391.

2 Lima MAC, Garcia RO, Martins GS, Mansur E. Morfogênese in vitro e susceptibilidade de calos de variedades nacionais de cana-deaçúcar (Saccharum officinarum L.) a agentes seletivos utilizados em sistemas de transformação genética. Rev Bras Bot 2001;24(1):73-77. DOI: http://dx.doi.org/10.1590/S010084042001000100008.

3 Fluminhan A. Cultivo in vitro de milho (Zea mays L.) e análise de sua instabilidade mitótica. [dissertação]. Piracicaba, SP: Escola Superior de Agricultura "Luiz de Queiroz", Universidade de São Paulo; 1992.

4 Lee TSG. Micropropagação de cana-deaçúcar através de cultura de meristema apical. Saccharum APC 1984;7(1):36-39.

5 Murashige T, Skoog F. A revised medium for rapid growth and bio assays with tobacco tissue cultures. Physiol Plant 1962;15(3):473497. DOI: http://dx.doi.org/10.1111/i.13993054.1962.tb08052.x

6 Silva FAS, Azevedo CAV. A new version of the Assistat -Statistical Assistance Software. In: Proceedings $4^{\text {th }}$ World Congress on Computers in Agriculture, 2006; Orlando. 
Orlando, FL: American Society of Agricultural and Biological Engineers; 2006. p. 393-396.

7 Silva FAS e, Azevedo CAV de. Principal components analysis in the software assistatstatistical assistance. In: Proceedings 7th World Congress on Computers in Agriculture, 2009; St. Joseph. St. Joseph: American Society of Agricultural and Biological Engineers, 2009. CD-Rom.

8 Lima IGGM. Avaliação do potencial morfogenético de genótipos de cana-deaçúcar cultivados in vitro e análise da sua instabilidade mitótica. [dissertação]. Presidente Prudente-SP: Universidade do Oeste Paulista; 2013.

9 Buitelaar RM, Tramper J. Strategies to improve the production of secondary metabolites with plant cell cultures: a literature review. J Biotechnol 1992; 23:111141.

10 Morini S, Marzialetti P, Babuiere C. In vitro growth response of Prunnus cerasifera shoots as influenced by different light-dark cycles and sucrose concentrations. Plant Cell Tissue Organ Cult, 1991;28:245-248.

11 Ertola RJ, Giulietti AM, Castillo FJ. Design, formulation, and optimization of media. In: Bioreactor System Design. Marcel Dekker: New York, 1995. p. 109-121.

12 Ibaraki Y, Kurata K. Automation of somatic embryo production. Plant Cell Tissue Organ Cult, 2001;65:179-199.

13 Woodward AW, Bartel B. Auxin: regulation, action and interaction. Ann Bot, 2005;95:707-735. DOI: http://dx.doi.org/10.1093/aob/mci083.

14 Aguiar-Perecin MLR de, Fluminhan A. Mitotic instability in callus cultures of inbred lines adapted to tropical regions. Maize Genet Coop News Lett, 1992; 66:87-88.
15 Drapeau D, Blanch HW, Wilke CR. Growth kinetics of Dioscorea deltoidea and Catharanthus roseus in batch culture. Bioengineering and Biotechnology, 1986;28(10):1555-1563. DOI: http://dx.doi.org/10.1002/bit.260281014

16 Zhong JJ, Yoshida T. High-density cultivation of Perilla frutescens cell suspensions for anthocyanin production: effects of sucrose concentration and inoculum size. Enzyme Microb Technol, 1995;17:1073-1079.

17 Scandolieri RF, Koyanagui AP, Takahashi FT, Fluminhan A. Changes in chromosomes in highly embryogenic cultured cells and in germinating stored seeds of maize. Maize Genet Coop News Lett, 2004; 40:91-92.

Recebido para publicação em 20/08/2014 Revisado em 22/08/2014

Aceito em 22/09/2014 